\title{
DETERMINANTS OF INTENSITY OF SOYBEAN COMMERCIALIZATION AMONG SMALLHOLDER FARMERS IN BUTERE, KENYA
}

\author{
Martha Wanjiru GACHUHI $^{* 1}$, George OWUOR ${ }^{1}$ (i) Edith GATHUNGU ${ }^{1}$ (i)
}

\author{
Address: \\ ${ }^{1}$ Egerton University, Faculty of Agriculture, Department of Agricultural Economics and Agribusiness Management, \\ P.O Box 536-20115, Egerton Njoro, Kenya. \\ * Corresponding author: mcirug@gmail.com,phone: +254 728957684
}

\begin{abstract}
Research background: Soybean commercialization plays a vital role in enhancing the livelihoods, and income of smallscale farmers. Despite the government efforts to boost agricultural commercialization in Kenya, the intensity of soybean commercialization in the Butere Sub-County has remained low for unknown reasons.

Purpose of the article: This study investigates factors influencing the intensity of soybean commercialization in Butere Sub-county with an aim of recommending policies for improving the effectiveness and efficiency of the soybean commercialization process to improve rural livelihoods as well as realize major economic goals.

Methods: A sample of 201 smallholder soybean farmers was selected using a multistage sampling procedure. Face to face interviews using a pretested semi-structured questionnaire was used to collect the data. Data analysis was done using descriptive statistics and a double hurdle regression model.

Findings \& Value added: The results revealed a relatively low soybean commercialization level (56.72 \%) among soybean-producing households in the study area with schooling years, the number of extension contacts, and total land size under soybean production positively and significantly influencing soybean commercialization decisions. Similarly, schooling years, the number of extension contacts, and total land size under soybean production positively and significantly determined the intensity of soybean commercialization. The study, therefore, recommends equitable access to agricultural resources by all gender, the creation of exclusive land ownership rights, and the structuring and strengthening of the extension system.
\end{abstract}

Key words: soybean; intensity; commercialization; double hurdle model JEL Codes: C01; C13; C31; Q12

\section{INTRODUCTION}

Globally, agricultural commercialization plays a passive and supportive role in economic growth and development (Leavy and Poulton, 2007; Kirsten et al., 2012; Todaro and Smith, 2015). Agricultural commercialization represents a major transformation in the sector of agriculture that aims at improving the livelihoods of many small-scale farmers through employment creation, increased incomes, and food and nutritional security (Todaro and Smith, 2015). As efforts proceed to further transform the agricultural sector to help boosts the livelihoods of rural farmers in developing countries, much of the discourse focuses on agricultural commercialization (World Bank, 2008).

Lapar et al. (2003) defined agricultural commercialization as any market-oriented activity conducted to promote the sale of produce. They added that it represents produce sales as a fraction of total output. According to Jagwe et al. (2001), commercialization refers to market participation that involves a transition from subsistence farming to market engagement networks as well as frequent use of market institutions and market infrastructures to trade agricultural products and services. The process usually involves a gradual change from subsistence to fully commercialized agriculture with the main aim of realizing various welfare effects (Pingali and Rosegrant, 1995). It involves farm households' decision to fully commercialize production when targeting output markets than being connected only to the volume of produce they would probably send to the market due to surplus production (Pingali and Rosegrant, 1995). It also relates to the agricultural production to meet specific output market needs as well as the supply of inputs for production to farmers (Jagwe et al., 2001; Brian and Barret, 2014).

Like in many developing countries, commercialization is not new in Kenya for it dates backs to more than five decades ago, but gained prominence during structural adjustment period when Kenya, with support from international development agencies, started implementing liberalization policies. (GoK, 1965; GoK, 1981; GoK, 1986, Rono, 2002; GoK, 2004; GoK, 2005; GoK, 2007; GoK, 2010; GoK, 2017). Focusing on the 
Strategy for Revitalization of Agriculture (SRA), Agricultural Sector Transformation and Growth Strategy (ASTGS), and Agricultural Sector Development Strategy (ASDS), commercialization was identified among transformational strategies for realizing food security and eradicating poverty in Kenya. The sole purpose of these major economic policies was to change Kenya's agricultural sector from subsistence farming to a market oriented and profitable economic activity (GoK, 2005; GoK, 2010). Additionally, the implementation of these market liberalization policies shifted agricultural development from subsistence farming to agribusiness by promoting transparent agricultural input and output markets, agribusiness-oriented culture, access to agricultural credit, and efficient use of farming inputs (GoK, 2007; GoK, 2010).

Importantly, agricultural stakeholders have overtime emphasized legume commercialization. This is because legumes are important sources of nutrients (protein and oils) in human diet and positively contribute to soil fertility through biological nitrogen fixation, income, and livelihoods of many households (Chianu et al., 2006; Varia, 2011). However, it is crucial to acknowledge that given the human and industrial demand for other legumes such as soybean, Glycine max (L.) Merrill, research organizations are increasingly developing and disseminating soybean technology with the view of encouraging soybean production, as well as commercialization. Soybean commercialization enables farmers to increase farm margins or income from higher yields for improved living standards (Osmani et al., 2015). In this regard, various development partners have been promoting soybean production as well as its commercialization activities especially in many developing countries (Varia, 2011).

Soybean production and commercialization are largely practiced by small-scale producers with limited capability to deal with agricultural production and commercialization challenges such as market inaccessibility, pests, and diseases, effects of climate change, and many more (Idrisa et al., 2010). Soybean production is largely done in western part of Kenya such as Vihiga, Busia, Kakamega, and Bungoma. In these areas, soybean is majorly intercropped with stable crops, however, this is far below the current production potential and market demand (Rachier, 2001, Nyongesa et al., 2017). According to Mahasi et al. (2011) over 2,500 hectares of total arable land in Kenya is under soybean production. Importantly, the production per hectare in Kenya averages at 0.8 tonnes, and which is far below the average potential of 3.0 tonnes per hectare. Currently, demographic shifts as resulted in an increase in the industrial demand for soybean and products as nutritious and safer food and raw material for the making livestock feed as well as human food (Chianu et al., 2009; AGRA, 2017). This presents an opportunity to promote soybean commercialization especially among small-scale producers in Kenya. Commercialization, therefore, remains a major step towards realizing increased soybean productivity, increasing farm incomes (Nyongesa et al., 2017).
Increasing soybean production and commercialization activities is, therefore, vital in improving the livelihoods of small-scale farmers. In this regard, the government of Kenya among other stakeholders through a number of programs have come up with strategies to boost soybean commercialization in Kenya, especially in Butere SubCounty. Despite these efforts as well as an increased marketing opportunity, commercialization of soybean in Butere Sub-County has remained low for unknown reasons. Little exists on factors that determine the intensity of soybean commercialization among small-scale farmers. Therefore, understanding determinants of intensity of soybean commercialization among smallholder farmers through this study remains valuable in meeting the current and future demand for soybean and soybean products, while contributing to improved rural livelihoods.

In light of the foregoing, and based on quantitative study design, this identified the factors influencing the intensity of soybean commercialization using a more comprehensive farm-level index and more robust and recent econometric models. This study adds to the existing empirical literature on the determinants of soybean commercialization intensity. From the results, a number of policy recommendations are discussed to improve the effectiveness and efficiency of the soybean commercialization process to realize major economic goals i.e. the big four Agenda of realizing food security and Sustainable Development Goals (SDGs) of meeting zero hunger.

This paper proceeds as follows; section two presents the literature review and section three presents the research methodology of the study. Section four presents the study results and discussions. Finally, section five presents the conclusion and policy recommendations derived from the findings.

\section{LITERATURE REVIEW}

Commercialization refers to market participation that involves a transition from subsistence farming to market engagement networks as well as frequent use of market institutions and market infrastructures to trade agricultural products and services (Jagwe et al., 2001). Soybean commercialization literature, which includes the factors influencing soybean commercialization decision, intensity, and impacts on welfare, presents diverse results based on the place of the study, welfare indicators, and other factors. Zamasiya et al. (2014) studied factors influencing the decision to participate in soybean markets and extent of a farmer's participation in the market using Heckman's Probit model with sample selection, and found inoculants, improved soybean seed varieties, ownership of radios, quantity produced, marital status, and education to be significant determinants. Mbembe et al. (2019) also found that the quantity of seed planted, fertilizer, access to credit, and use of inoculants positively affected the probability of soybean commercialization. They added that the intensity of soybean market participation was influenced by the quantity of seed planted, the quantity of soybean harvested, output price, use of fertilizer, and access to the extension positively. In a related study on beans, Mbitsemunda and Karangwa (2017) identified 
factors such as farm size allocated to beans, access to market information, market experience, bean quantity produced, access to credit, and access to irrigation as determinants of the degree of commercialization measured using Household Commercialization Index (HCI) in Nyanza District, Rwanda. Nonetheless, Zamasiya et $\boldsymbol{a l}$. (2014) added that the extent of market participation among small-scale soybean farmers in the market remains low due to many constraints.

Importantly, according to Nyein et al. (2018), most of the smallholder farmers resides in rural areas with the underdeveloped market and transport infrastructures, leading to high transportation and transaction cost. Key (2000) added that these smallholder farmers lack reliable information on potential markets as well as information on potential customers. Due to their poor production techniques, smallholder farmers tend to produce small surpluses thus generally exposed to a higher degree of transaction costs and risk (Omiti et al., 2009). This normally forces smallholder farmers to sell their soybean produce at low-value market outlets such as farm gate and village markets. Generally, the decision to sell as well as the quantity of soybean to take to the market are mainly determined by market prices, distance to the market, and amount of marketing information available (Omiti et al., 2009; Zamasiya et al., 2014). Consequently, the reviewed empirical literature shows the determinants of agricultural commercialization analysed using different approaches for different crops in Kenya and beyond. Previous studies have made a significant contribution to understanding factors influencing smallholder commercialization. However, no study has explicitly and empirically studied the determinants of intensity of soybean commercialization among smallholder producers in Butere Sub-county, Kenya.

\section{DATA AND METHODS}

\section{Study Area}

This study was carried out in Kakamega County, Butere sub-county located in the western part of Kenya. The SubCounty occupies approximately $210.6 \mathrm{Km}^{2}$, with a human density of 186 persons per square kilometre, totalling a population of 154,100 people (KNBS, 2019). The subcounty is located between the longitude $34^{\circ} 45^{\prime} 0.00^{\prime \prime}$ East and latitude $0^{\circ} 16^{\prime} 60.00^{\prime \prime}$ North. Butere Sub-County experiences a bimodal rainfall pattern; where the long rains occur between March and July while short rains occur between August and October, with annual rainfall amount ranging between 1280.1- $2214.1 \mathrm{~mm}$ per annum. The Sub-County is located at an altitude ranging from 1240 meters to 2000 meters above sea level with temperatures ranging from 18 to 29 degrees Celsius. Higher temperatures are recorded in January, February, and March, with other months experiencing similar temperatures except for July and August with cold spells. Agriculture especially crop production remains the main economic activity in the area. Butere is characterized by fertile and well-drained soils which support the production of major crops like soybean, sugar, maize, beans, horticulture etc. Smallholder maize production dominates the area. The choice of the study area was motivated due to the fact that most of the small-scale farmers are engaging in soybean production, as the area is suitable for soybean production. Again, the sub-county remains one of the areas in western Kenya where the government of Kenya among other development partners have widely promoted soybean production and commercialization (Mbembe et al., 2021).

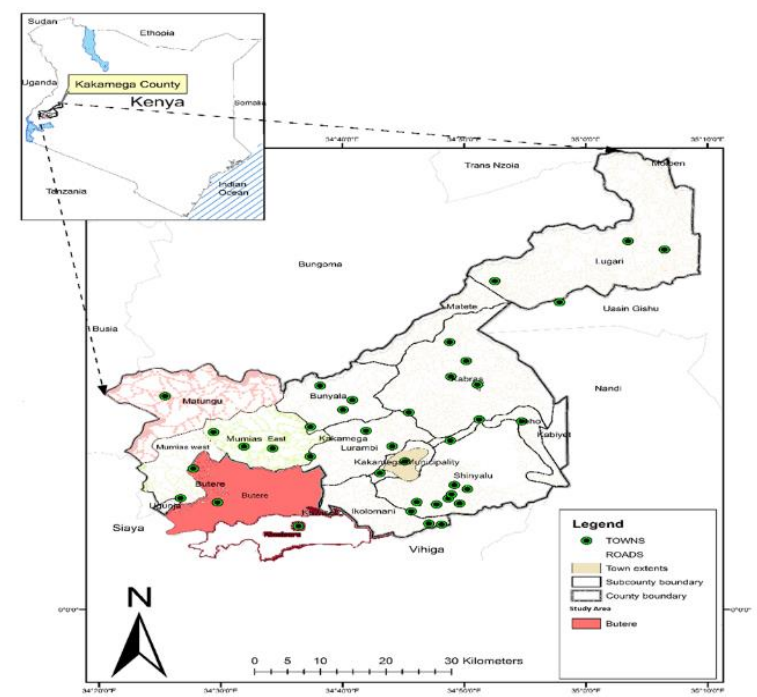

Figure 1. Map of Kakamega County showing the study area

\section{Sampling and Data Collection}

This study adopted exploratory research design. Smallscale farmers in Butere were the study target population, whereas the smallholder soybean farmers formed the sampling unit. Since the population of the smallholder soybean farmers was unknown, the study adopted Cochran's sample size determination formula to arrive at a sample size of 201 respondents (Cochran, 1997). Here, $Z$ as the critical value of the normal curve that cut off the area was estimated at $1.96, e$ as the desired level of precision set at $6.9 \%, p$ as the estimated proportion of attributes present in the population and $Q=1-P$. According to Cochran (1997), an error of less than $10 \%$ is usually acceptable. Therefore, assuming that , therefore, $Q=1-0.5 ; e=0.069$; and $z=1.96$, the sample was determined to be 201: A random sampling of 201 smallscale soybean farmers in the study area was done using a multistage random sampling technique.

The first stage involved a purposive selection of Kakamega County as one of the counties in the western region where soybean production is largely done. The second stage involved a purposive selection of Butere Sub-county as one of the leading soybean producing counties with low commercialization. Finally, a random selection of 201 soybean farmers was done from two purposively selected wards namely; Masaba and West Marama. In other words, a proportionate to size distribution sampling was used based on the targeted number of the producers and total number of smallholder farmers in selected wards, and this resulted in 114 randomly selected soybean households from West Marama, since majority of farmers there are engaging in the commercialization of soybean. 87 randomly selected 
soybean households from Masaba ward was done, since soybean commercialization remains low.

This study used face-to-face interviews with semistructured questionnaires to collect primary data from the selected respondents. The questionnaire was first pretested before the actual data collection using 15 farmers in sample households. This was done to enable the correction of mistakes, thus improving the quality, accuracy and reliability of the data collected. The information collected consisted of soybean production and commercialization activities in the year 2018. Most respondents were household heads who were participating in soybean marketing in the last season of the year. A group of trained enumerators through personal interviews administered the questionnaires. Data were then entered and analysed using the STATA computer software.

\section{Analytical Framework}

Previous empirical studies on commercialization have characterized farmer decision to commercialize as a twostep decision-making process. The first step is conceived as involving farmers' decision to participate in the market or not. In the second step, farmers' who choose to participate in the market must decide on the volume of the commodity to sell. The empirical estimation of the twostep decisions usually involves fitting a double hurdle model. Most of the empirical studies (Mathenge et al., 2010; Woldeyohanes et al., 2016; Camara, 2017) have applied a double hurdle model to separate farmers who participate in the market from those do not, in the first step. The first hurdle involves the estimation of a probit model. The second step involves the estimation of a truncated or censored tobit regression for the quantities of produce sold in the market. This implies that double hurdle regression model is the appropriate model for estimating two-step models when the targeted group of farmers who are all producers (Burke $\boldsymbol{e t} \boldsymbol{a l}$., 2015). Therefore, following Burke et al. (2015) approach, this study adopted a double hurdle model in estimating factors influencing intensity of soybean commercialization among smallholder farmers in the Butere. This is because the study targets only a group of farmers who are soybean producers. Therefore, the decision to commercialize soybean was regarded as the initial condition for commercialization. Burke et al. (2015) noted that although production is an initial decision, it may result from a completely different structural decision making process compared to the decision to commercialize production and the intensity of commercialization. Thus, this allows the decision to participate in the market and the intensity of participation to be modelled using a two-step approach. Here, the first step examined the factors associated with whether or not to sell soybean in the market. The last step estimates the intensity of market participation or commercialization measured using the Household Commercialization Index (HCI) as follows (Eq.1);

$H C I=\left(\frac{\text { Total Value } / \text { Quanity of Soybean Sold }}{\text { Total Soybean production Value }}\right)$
The first step of Double Hurdle Model involved estimating a probit model. Following Wooldridge (2013) the decision whether or not to commercialize was estimated as shown in Eq. (2).

$p_{i}^{*}=\delta+x_{i}+\epsilon_{i}$
$p_{i}=\left\{\begin{array}{c}1 \text { if } p_{i}^{*}>0 \\ 0 \text { otherwise }\end{array}\right.$

Where:

$p_{i}^{*}$ was the underlying latent variable representing changes in utility or net benefit for commercializing soybean production. $p_{i}=1$ was if a household participated in soybean output market (commercialized), and 0 otherwise (non-commercialization). $\varphi$ was the vector of parameters to be estimated. $X_{i}$ was the vector of explanatory variables and $\varepsilon_{i}$ was independent identically distributed error terms.

In the last step, a truncated Tobit regression was estimated for the determinants of intensity of soybean commercialization as shown in Eq. (3).

$c=\beta_{0}+\beta x_{i}+\mu_{i}$

Equation (2) represented the probability of smallholder farmer's commercializing soybean production which is a binary choice of whether to commercialize or not. The probability of commercializing soybean picks the value of 1 if the farmer participates in the soybean output market or zero otherwise. $c$ in Equation (3) represented the intensity of commercialization (the quantity of soybean sold in the market) measured in terms of the Household commercialization index, which is the ratio of quantity of produce taken to the market to the total quantity produced by households. Turning to other terms in the Double Hurdle Model in Equation 3, $X$ represents a vector of explanatory variables, $\beta$ represents parameters to be estimated and associated with the explanatory variables. $\delta, \beta_{0}$ are intercepts for Equation 2, and Equation 3, respectively. Lastly, $\varepsilon_{i}, \mu_{\mathrm{i}}$ are stochastic disturbance terms.

The study expected that the intensity of soybean commercialization was enhanced or constrained by a number of factors. Farm characteristics were also expected to have either a positive or a negative effect on the intensity of soybean commercialization Infrastructural factors also were expected to constrain smallholder farmer participation in soybean marketing as well as the intensity of commercialization. Similarly, socio-economic characteristics (age, education, household size, farming experience, gender, and income) were also expected to either constrain or encourage the intensity of soybean commercialization.

\section{RESULTS AND DISCUSSION}

\section{Descriptive statistics}

Descriptive statistics of the soybean households in Butere Sub-County are presented in Table 1 . The study revealed that the majority of the sampled households (approximately 57\%) were participating in soybean commercialization, even though the intensity varies. 
Results also showed that the commercialization level for West Marama ward was $63 \%$ and that of Masaba ward was $33 \%$. This justifies our assumption on the level of soybean commercialization in the two wards. Further, a higher percentage of sampled soybean households were maleheaded regardless of whether they commercialized soybean production $(61.60 \%)$ or not $(70.11 \%)$. Similarly, a higher percentage were married regardless of whether they commercialized $(71.93 \%)$ or not $(81.39 \%)$. Descriptive results further revealed that a larger proportion of soybean farmers who commercialized soybean production $(80.70 \%)$ as well as those who did not commercialize $(73.56 \%)$ were engaging in crop and livestock farming as their primary occupation. The results further revealed that, on average, non-commercialized soybean farmers were significantly older (59.05 years) than commercialized soybean farmers ( 50.25 years). This could be attributed to the unattractiveness of soybean production and marketing among the older farmers due to high labour requirement for the production and marketing of soybean.

Results also revealed that commercialized soybean farmers had on average, significantly higher levels of education (10 years) compared to non-commercialized soybean farmers (7 years). Educated farmers are much informed and can effectively search and interpret agricultural information on modern technologies to produce a surplus for the market (Awotide $\boldsymbol{e t}$ al., 2016). Non-commercialized soybean households had on average, significantly large household sizes ( 7 members) compared to commercialized soybean households (5 members), and this is attributed to the fact that large households have more mouths to feed thus require more food which lowers the amount of surplus available for the market. On average, commercialized soybean households had significantly more years of experience $(7$ years) in soybean production than non-commercialized household (5 years). Further, t-test results revealed that on average, there was no statistically significant difference in the annual incomes of commercialized and noncommercialized soybean households. Type of soil fertility plays a vital role in enhancing the quantity of soybean produced. Descriptive statistics showed that commercialized soybean households had significantly more fertile plots $(74.56 \%)$ than non-commercialized soybean households $(68.51 \%)$. The majority of those who engaged in soybean commercialization (95.61\%) and those who don't (93.10\%) owned their plots with titles. On overage, commercialized soybean farmers significantly allocated bigger farms size for soybean production ( 0.37 acres) compared to non-commercialized farmers $(0.23$ acres $)$. Greater allocation of land for soybean production increases production levels, as well as surplus level, hence increasing the likelihood of agricultural commercialization.

A higher proportion of commercialized soybean households did not have access to credit (57.02\%) compared to the non-commercialized soybean farmers $(50.57 \%)$. On average, the results further showed that commercialized soybean households significantly had a higher extension visits (5) compared to noncommercialized soybean households (2). The majority of the surveyed respondents had membership in active farmer groups $(61.69 \%)$. On average, commercialized soybean farmers were significantly living near market centres (16 walking minutes) compared to noncommercialized soybean farmers (35 walking minutes). Soybean Household Commercialization Index was measured as; the total amount of soybean sold in the market from own production over the total amount of soybean produced on the farm. The average Household Commercialization Index of soybean in Butere SubCounty was 0.38 . Overall, this implies that soybean households in the Butere Sub-County were marketing on average about $38 \%$ of the total value of soybean produced. Therefore, they were consuming more than $62 \%$ of the total value of all soybean harvested. The low level of soybean commercialization was, therefore, evident in Butere Sub-County. For the non-commercialized soybean households, the average commercialization index as a measure of the intensity of commercialization was 0 . For commercialized soybean households, the average commercialization index as a measure of the intensity of commercialization was 0.68 . This implies that commercialized households sold on average about $68 \%$ of the total value of soybean they produced. Therefore, commercialized soybean households were only consuming less than $32 \%$ of the total amount of soybean they harvested. This is a clear indication of a high soybean commercialization level among commercialized soybean households.

\section{Factors influencing intensity of soybean commercialization among smallholder farmers in Butere Sub-county, Kenya}

Even though the decision to sell soybean as well as the intensity of commercialization can be modelled independently, either by using a probit/ logit and Tobit models, respectively, such econometric modelling may result in biased and inefficient parameters estimates. This is because such estimation ignores the potential correlation between the unobserved error terms of the two decisions; that is the decision on the volume of soybean to sell is dependent on the initial decision to commercialize soybean. In this regard, a double hurdle model with sample selection problems was run to solve the problem.

The double hurdle regression model was then used to determine factors affecting the decision to commercialize soybean (binary) and intensity commercialization (HCI) among smallholder farmers in Butere. The results of the maximum likelihood estimation for a double hurdle regression model, using the craggit command, for the decision to commercialize soybean and intensity of soybean commercialization, are presented in Table 2 . However, it was vital to first test whether the double hurdle regression model was preferred over the Tobit regression model or Heckman model using the loglikelihood ratio (LR) statistic. In this regard, the suitability of the double hurdle regression model against a Tobit model was checked using a likelihood ratio test. In this study, the LR test statistic was 146.45, and it was significant at a $1 \%$ level. Therefore, this test statistic showed that the double hurdle model was strongly preferred to other specification. This indicates that two 
separate decision-making stages exist where soybean farmers make independent decisions regarding whether to commercialize or not and the intensity of commercialization. Also, the Tobit model is restrictive therefore unable to make any distinction between the two stages of commercialization decision-making the process. Besides, since dependent variable in second tier is a ratio, double hurdle seems to be the best as it use maximum likelihood estimation than Heckman that uses least square regression in the second tier.

Post-estimation tests were also conducted to check the correctness, fitness, and robustness of the double hurdle regression model. The test for multicollinearity among the independent variables was conducted using variance inflation factors (VIF), and the results in Table 2. The result show that all VIF values were below the recommended value of 3.3 , with an average of VIF of 1.15. This implied that multi-collinearity existed between the predictors (Greene, 2018; Hair et al., 2011; Knock and Lynn, 2012). Pairwise correlation test results confirmed that there was no multicollinearity among the categorical independent variables because the pairwise correlation coefficients were all less than the recommended value of 0.75 in all cases (Greene, 2018). The results of the Breusch- Pagan test revealed that we could not reject the null hypothesis of homoscedasticity $(p=0.1077)$. This showed that the double hurdle model was free from heteroscedasticity. However, to counter further heteroscedasticity problem, robust standard errors were used in all the analyses.

Table 1: Soybean Commercialization. Descriptive statistics

\begin{tabular}{|c|c|c|c|c|c|}
\hline \multirow[t]{2}{*}{ Variables } & \multirow[t]{2}{*}{ Description } & Overall $(n=201)$ & $\begin{array}{l}\text { Commercialized } \\
(\mathrm{n}=114)\end{array}$ & $\begin{array}{l}\text { Non- } \\
\text { commercialized } \\
(n=87)\end{array}$ & \multirow[t]{2}{*}{$\begin{array}{l}C h i^{2} \text { value / } \\
\text { t-value }\end{array}$} \\
\hline & & Mean/ Percent & Mean/ Percent & Mean/ Percent & \\
\hline \multicolumn{6}{|l|}{ Socio-economic } \\
\hline \multirow[t]{2}{*}{ Gender of the house head } & Male & 65.17 & 61.60 & 70.11 & \multirow[t]{2}{*}{1.65} \\
\hline & Female & 34.83 & 38.60 & 29.89 & \\
\hline \multirow{4}{*}{$\begin{array}{l}\text { Marital status of household } \\
\text { head } \\
\text { Primary occupation of the } \\
\text { head }\end{array}$} & Married & 76.12 & 71.93 & 81.39 & \multirow[t]{2}{*}{2.54} \\
\hline & Not married & 23.88 & 28.07 & 18.39 & \\
\hline & $\begin{array}{l}\text { Crop/livestock } \\
\text { farming }\end{array}$ & 77.61 & 80.70 & 73.56 & \multirow[t]{2}{*}{3.74} \\
\hline & $\begin{array}{l}\text { Non-farm } \\
\text { employment }\end{array}$ & 22.39 & 19.30 & 26.44 & \\
\hline Age of household head & Years & $54.04(0.85)$ & $50.25(1.11)$ & $59.05(1.12)$ & $5.47 * * *$ \\
\hline Years of schooling of head & Years & $8.89(0.27)$ & $10.39(0.28)$ & $6.92(0.40)$ & $-7.22 * * *$ \\
\hline Household size & Number & $5.81(0.19)$ & $4.72(0.17)$ & $7.22(0.33)$ & $7.19 * * *$ \\
\hline $\begin{array}{l}\text { Household head } \\
\text { experience in soybean } \\
\text { production }\end{array}$ & Years & $6.30(0.43)$ & $7.12(0.62)$ & $5.23(0.52)$ & $-2.22 * *$ \\
\hline Annual income & US\$ & $463.83(40.46)$ & $506.23(52.66)$ & $408.27(629.1)$ & -1.20 \\
\hline \multicolumn{6}{|l|}{ Farm } \\
\hline \multirow[t]{2}{*}{ Soil fertility } & Fertile & 91.54 & 74.56 & 68.51 & \multirow[t]{2}{*}{$5.16^{*}$} \\
\hline & Not fertile & 8.46 & 24.44 & 31.49 & \\
\hline \multirow[t]{2}{*}{ Land tenure } & $\begin{array}{l}\text { Owned with } \\
\text { title }\end{array}$ & 94.53 & 95.61 & 95.4 & \multirow[t]{2}{*}{2.66} \\
\hline & $\begin{array}{l}\text { Owned without } \\
\text { title }\end{array}$ & 5.47 & 4.39 & 4.60 & \\
\hline \multicolumn{6}{|l|}{ Institutional } \\
\hline \multirow[t]{2}{*}{ Credit Access } & Yes & 45.77 & 42.98 & 49.43 & \multirow[t]{2}{*}{0.83} \\
\hline & No & 54.23 & 57.02 & 50.57 & \\
\hline \multirow[t]{2}{*}{ Group membership } & Yes & 61.69 & 66.30 & 57.80 & \multirow[t]{2}{*}{1.53} \\
\hline & No & 38.31 & 33.70 & 42.20 & \\
\hline $\begin{array}{l}\text { Extension Visit } \\
\text { Market }\end{array}$ & Number & $4(0.35)$ & $5(0.54)$ & $2(0.30)$ & $-4.82 * * *$ \\
\hline $\begin{array}{l}\text { Distance to the nearest } \\
\text { market }\end{array}$ & $\begin{array}{l}\text { Walking } \\
\text { minutes }\end{array}$ & $24.30(2.24)$ & $16.35(1.11)$ & $34.71(2.11)$ & $8.20 * * *$ \\
\hline Soybean & Yes & 56.72 & 56.72 & 43.28 & \\
\hline commercialization & No & 43.28 & 0 & 0 & \\
\hline
\end{tabular}

decision

Note: $* * *$ and $* * *$ is significant at $10 \%, 5 \%$ and $1 \%$ level, respectively. Standard deviations are in parenthesis. T- test was used since we assumed that the variables in question are normally distributed in the two groups 
Also, the sigma constant was relatively high (0.179) and statistically significant at $1 \%$ level (Table 2 ). Sigma constant measures the correlation coefficient between the first tier model (Decision to commercialize soybean) and the second tier model (soybean commercialization intensity model). The significant value of sigma constant statistic is a clear image of strong dependence between the two double hurdle tiers, thus supporting the appropriateness of the model approach over the Tobit specification (Wooldridge, 2010). Again, the log pseudolikelihood for the fitted model was -22.164 and Wald chi ${ }^{2}$ (15) of 74.12, (Prob $>\chi^{2}=0.000$ ), indicating that all parameters are jointly significant and all independent variables included in the double hurdle models explained the decision to commercialize soybean and intensity of soybean commercialization at $1 \%$ significance level.

The model revealed a vector of variables significantly influencing soybean commercialization decision and intensity of commercialization. Regarding household characteristics, the results in Table 2 showed that the primary occupation of the household head was negatively and significantly related to the soybean commercialization decision and intensity of soybean commercialization at $10 \%$ and 5\% levels, respectively. Farmers engaging in crop and livestock farming as their primary occupation were more likely to commercialize soybean production compared to those engaging in non-farm employment as a primary occupation. Household participation in off-farm duty as their primary occupation often limit the time available for soybean production and thus discouraging uptake of the labour-intensive technologies that would result in higher soybean yield and surplus for markets. The intensity of soybean commercialization for household primarily engaging in off-farm jobs was significantly lower than that of farmers primarily engaging in crop and livestock farming by $17.4 \%$, at a $5 \%$ significance level, ceteris paribus. This finding is similar with those from a study by Wollni et al. (2010) who found that participation in off-farm work negatively affects the adoption of labourintensive conservational technologies thus lowering yield and surplus for sale.

The age of the household head had a negative and significant influence on the decision to commercialize soybean as well as soybean commercialization intensity both at a $1 \%$ significance level. This shows that the elder farmer is, the lesser the likelihood of participating in the soybean market. This implies that if the age of the household head increases by one year it reduces the intensity of soybean commercialization by 0.010 , ceteris paribus. This could be attributed to the unattractiveness of soybean production and marketing among the older farmers due to high labour requirement for the production and marketing of soybean. Besides, younger farmers are less risk-averse and more adaptable innovative, and hence able to continuously adopt new technologies like improved soybean seeds which makes them produce surpluses for the markets compared to older farmers (Onyeneke, 2017).

Education of the household head also had a positive and significant effect on the decision to commercialize soybean and intensity of soybean commercialization both at a $1 \%$ significance level. This implies that the more educated a household head is, the higher the likelihood of participating in soybean commercialization. A one-year increase in years of schooling was likely to increase soybean commercialization intensity by 0.029 , ceteris paribus. This could be attributed to the fact that education equips farmers with more agricultural information and skills that enable them to make commercialization decision accurately, hence increasing their participation in the soybean market and in a more profitable way. Again, educated farmers are able to adopt new production technologies thereby increasing their production and surplus level. These results were consistent with findings from other studies by Omiti et al. (2009) and Mottaleb et al. (2015).

Further, household size was negatively and significantly related to the soybean commercialization decision and intensity of soybean commercialization both at a $1 \%$ significance level. This shows that if the household size increases by one member it decreases the probability of participating in soybean commercialization. Also, a unit increase in household size decreases the intensity of soybean commercialization by 0.277 , ceteris paribus. Households with more members often have more mouths to feed thus associated with higher demand for food compared to households with fewer members. Larger household size thus requires more food from available produce which lowers the amount of surplus available for the market. This finding is consistent with that from Turaa et al. (2016).

The total amount of annual household income from other sources other than soybean production had a negative and significant influence on soybean commercialization decision at $10 \%$ level. The results indicated that an increase in the total amount of annual household income from other sources reduces the probability of household soybean commercialization. A negative effect of the amount of income from other sources on commercialization decision could be attributed to the fact farmers invest less of such funds on activities to increase soybean yields and surplus. Also, they spend much income to expand other activities instead of soybean production. Again, an increased amount of total annual income reduces the farmers' incentive to commercialize its soybean production probably because they have alternative income sources. A similar finding was found by Kpadonou et al. (2017). However, the amount of income received from other sources had an insignificant effect on the intensity of soybean commercialization.

The total land under soybean production was found to affect positively and significantly the decision to commercialize soybean and commercialization intensity both at $1 \%$ level. By implications, farmers who allocated a large piece of land for soybean production are more likely to participate in commercialization, compared to those allocating small land sizes. Again, when all other factors are held constant, a unit increase in the total land under soybean production was found to increase the intensity of soybean commercialization by about 0.340 (Table 2). Greater allocation of land for soybean implies a greater access to land, higher production levels, as well as higher surplus level, hence increasing the probability as well as the intensity of soybean commercialization. 
Table 2: Double hurdle with selection estimation results for soybean commercialization decision and intensity of soybean commercialization

\begin{tabular}{|c|c|c|c|c|}
\hline \multirow[b]{2}{*}{ Variable Description } & \multicolumn{2}{|c|}{$\begin{array}{l}\text { Probit } \\
\text { Commercialization decision model } \\
\text { (Selection equation) } \\
1=\text { Commercialized, } 0=\text { Non- } \\
\text { commercialized }\end{array}$} & \multicolumn{2}{|c|}{$\begin{array}{l}\text { Truncated Tobit Regression } \\
\text { Intensity of Commercialization model } \\
\text { (HCI) } \\
\text { (Outcome equation) }\end{array}$} \\
\hline & Coefficient & Standard Error & Coefficient & Standard Error \\
\hline \multicolumn{5}{|l|}{ Socio-economic characteristics } \\
\hline Gender of household head ( $1=$ Male, $0=$ Female $)$ & -0.164 & 0.417 & 0.054 & 0.085 \\
\hline Marital status of household head ( $1=$ Married, $0=$ Not married $)$ & 0.053 & 0.495 & -0.094 & 0.010 \\
\hline $\begin{array}{l}\text { Primary occupation of the head }(1=\text { Crop and livestock farming, } 2=\text { non-farm } \\
\text { employment) }\end{array}$ & -0.638 & $0.355^{*}$ & -0.174 & $0.075 * *$ \\
\hline Age of household head (Years) & -0.055 & $0.014 * * *$ & -0.010 & $0.003 * * *$ \\
\hline Years of schooling of household head (Years) & 0.122 & $0.036 * * *$ & 0.029 & $0.009 * * *$ \\
\hline Household head experience in soybean (Years) & -0.017 & 0.024 & -0.006 & 0.004 \\
\hline Household size (Number) & -0.277 & $0.062 * * *$ & -0.081 & $0.014 * * *$ \\
\hline Natural logarithm of other income & -0.183 & $0.101 *$ & -0.040 & 0.026 \\
\hline \multicolumn{5}{|l|}{ Farm Characteristics } \\
\hline Total land under soybean production (Acres) & 2.058 & $0.758 * * *$ & 0.340 & $0.121 * * *$ \\
\hline Soil fertility $(1=$ Fertile, $0=$ Not fertile $)$ & 0.551 & 0.435 & 0.142 & 0.111 \\
\hline Land tenure ( $1=$ Owned with title, $2=$ Owned without title) & -1.289 & $0.468 * * *$ & -0.141 & 0.142 \\
\hline \multicolumn{5}{|l|}{ Institutional Characteristics } \\
\hline Credit Access $(1=$ Yes, $0=$ No $)$ & 0.049 & 0.276 & 0.030 & 0.066 \\
\hline Group membership $(1=$ Yes, $0=$ No $)$ & -0.230 & 0.284 & -0.003 & 0.068 \\
\hline Extension visit (Number) & 0.154 & $0.043 * * *$ & 0.023 & $.006 * * *$ \\
\hline \multicolumn{5}{|l|}{ Market Characteristic } \\
\hline Distance to nearest market (Walking minutes) & -0.040 & $0.009 * * *$ & -0.011 & $0.002 * * *$ \\
\hline Constant & 7.365 & $1.638 * * *$ & 1.85 & $0.394 * * *$ \\
\hline Sigma constant & 0.178 & $0.012 * * *$ & & \\
\hline
\end{tabular}




\section{CONCLUSIONS AND IMPLICATIONS}

Understanding the determinants of intensity of soybean commercialization among small-scale farmers in the Butere sub-county is vital when designing sustainable 1 production and marketing policies. This study aimed to determine factors influencing the intensity of soybean commercialization in Butere Sub-County, Kakamega County. This study revealed significant variations in the farm, market, socio-economic, and institutional characteristics of sampled farmers. It was established that the average Household Commercialization Index of soybean in the Butere Sub-County was 0.38. In other words, the study showed that soybean households in Butere Sub-County were selling and consuming on average $38 \%$ and $62 \%$ of the total value of soybean produced, respectively. This showed that the soybean commercialization level in Butere Sub-County is relatively low.

Double hurdle model estimation revealed that important factors influencing the soybean commercialization decision in Butere Sub-County also influence its commercialization intensity. Therefore, this study concludes that a higher level of education, larger land area under soybean production and frequent extension visits increase households' participation in soybean commercialization. Further, ageing, participation in off-farm activities, larger household sizes, higher offfarm income, possession of land without title deed, as well as long-distance to the nearest market center discourage households to participate in soybean commercialization. Similarly, a higher level of education, larger land area under soybean production and frequent extension visits increase the intensity of soybean commercialization. Lastly, ageing, participation in the off-farm activity as a primary occupation, larger household size, and long distance to the nearest market center negatively affect the intensity of commercialization.

This study recommends policies such as fertilizer and seed subsidy policies that will ensure equitable access to production resources such as high yielding and fastmaturing soybean varieties and fertilizer by all gender to increase acreage and yields for soybean. Policies that ensure exclusive land ownership rights through the issuance of title deeds that thus leading to the expansion of actual land under soybean cropping are also encouraged. Polices are also needed to restructure and strengthen the extension system to facilitate frequent and timely provision of extension services as well as market information. There is a need for governments to consider policies that will ensure literacy development and training across all age brackets. Due to problems associated with cross-sectional data, future research should be more comprehensive in modelling the determinants of soybean commercialization intensity, using panel data to control for unobserved endogeneity and heterogeneity.

Acknowledgments: The authors acknowledge the technical assistance from university supervisors as well as farmers who participated in this study

\section{REFERENCES}

AGRA. Alliance for a Green Revolution in Africa. (2017). Soya bean farming untapped. Alliance for a Green Revolution in Africa. https://agra.org/wpcontent/uploads/2017/09/Final-AASR-2017-Aug28.pdf

AWOTIDE, B., KARIMOV, A., \& DIAGNE, A. (2016). Agricultural technology adoption, commercialization and smallholder rice farmers' welfare in rural Nigeria. Agricultural and Food Economics, 4(3), 1-24. https://doi.org/10.1186/s40100-016-0047-8

BRIAN, D., \& BARRETT, C. (2014). Agricultural Factor Markets in Sub-Saharan Africa: An Updated View with Formal Tests for Market Failure. Working Paper (No. 7117). World Bank Group, Washington, DC, 28 May.

https://openknowledge.worldbank.org/handle/10986/ $\underline{20648}$

BURKE, W., MYERS, R., \& JAYNE, T. (2015). A TripleHurdle model of production and market participation in Kenya's Dairy Market. American Journal of Agricultural. Economics, 97(4), 1227-1246. https://doi.org/10.1093/ajae/aav009

CAMARA, A. (2017). An analysis of the welfare effect of market participation of smallholder farm households in Guinea. The Economic Research Guardian, 7(1), 2-23. http://www.ecrg.ro/files/p2017.7(1)4y1.pdf

CHIANU, J., VANLAUWE, B., MUKALAMA, J., ADESINA, A., \& SANGINGA, N. (2006). Farmer evaluation of improved soybean varieties being screened in five locations in Kenya: implications for research and development. African Journal of Agricultural Research, 1(5), 143-150. https://academicjournals.org/article/article138078414 0_Chianu\%20et\%20al.pdf

COCHRAN, W. G. (1997). Sampling Techniques, 3rd Edition. Wiley Eastern: John Wiley \& Sons, Inc.

GOK. (1965). The Sessional Paper No. 10 of 1965 on African Socialism and its Application to Planning in Kenya. Nairobi: Government Printers.

GOK. (2010). Agricultural Sector Development Strategy 2010 - 2020. Government of Kenya. http://www.kenyagreece.com/sites/default/files/agricu ltural-sector-ds-2020.pdf

GOK. Government of Kenya (1981). National Food Policy paper. Sessional Paper 4. Nairobi: Government Printers

GOK. Government of Kenya (2004). The Economic Recovery Strategy for Wealth and Employment Creation 2003 - 2007. Nairobi: Government Printers.

GOK. Government of Kenya (2005). Economic Survey 2005. Nairobi: Government Printers.

GOK. Government of Kenya (2007). Kenya Vision 2030. Nairobi: Government Printers.

GOK. Government of Kenya (2008). Well-Being in Kenya: A socio-Economic Profile. Kenya National Bureau of Statistics. Nairobi: Government Printers.

GOK. Government of Kenya (2018). Eye on the big Four: Budget watch for 2018/19 and the medium term. Nairobi: Government Printers. 
GREENE, W. H. (2018). Econometric Analysis. $8^{\text {th }}$ Edition. Harlow, England: Pearson Education Limited.

IDRISA, Y. L., OGUNBAMERU, B. O., \& AMAZA, P.S. (2010). Influence of farmers' socio-economic and technology characteristics on soybean seeds technology adoption in Southern Borno State, Nigeria. African Journal of Agricultural Research, 5(12), 1394-1398. DOI: 10.4314/as.v9i3.65761

JAGWE, J., MACHETHE, C., \& OUMA, E. (2010). Transaction costs and smallholder farmers' participation in banana markets in the Great Lakes Region of Burundi, Rwanda and the Democratic Republic of Congo. African Journal of Agricultural and Resource Economics, 6(1), 302-317. URI: http://hdl.handle.net/2263/16631

KEY, N., SADOULET, E., \& JANVRY, A. D. (2000). Transactions costs and agricultural household supply response. American Journal of Agricultural Economics, 82, 245-259. https://doi.org/10.1111/0002-9092.00022

KIRSTEN, J., MAPIL, M., OKELLO, J., \& DE, S. (2012). Managing Agricultural Commercialization for Inclusive Growth in Sub-Saharan Africa. Global Development Network (GDN). The Global Research Capacity Building Program. http://www.gdn.int/admin/uploads/editor/files/SSA 1 ResearchPaper_Agricultural_Commercialization.pdf

KNBS (2019): 2019 Kenya Population and Housing Census. Government Printers. Nairobi: Kenya.

KPADONOU, R., OWIYO, T., BARBIER, B., DENTON, F., RUTABINGWA, F., \& KIEMA, A. (2017). Advancing climate-smart-agriculture in developing drylands: Joint analysis of the adoption of multiple onfarm soils and water conservation technologies in West Africa Sahel. Land Use Policy, 61, 196-207. https://doi.org/10.1016/j.landusepol.2016.10.050

LAPAR, M., HOLLOWAY, G., \& EHUI, S. (2003). Policy options promoting market participation among smallholder livestock producers: A case study from the Philippines. Food Policy, 28(3), 187-211 https://doi.org/10.1016/S0306-9192(03)00017-4

LEAVY J., \& POULTON, C. (2007). Commercialization in Agriculture. Ethiopian Journal of Economics, 16(1), 3-42. DOI: $10.4314 /$ eje.v16i1.39822

MAHASI, J. M., MUKALAMA, J., MURSOY, R. C., MBEHERO, P., \& VANLAUWE, B. (2011). A Sustainable Approach to Increased Soybean Production in Western Kenya. African Crop Science Conference Proceedings, 10, 111-116. https://www.cabdirect.org/cabdirect/abstract/2013320 $\underline{0226}$

MATHENGE, M., PLACE, F., OLWANDE, J., \& MITHÖFER, D. (2010). Participation in Agricultural Markets among the Poor and Marginalized: Analysis of Factors Influencing Participation and Impacts on Income and Poverty in Kenya. A study Report. Kenya: Tegemeo Institute of Agricultural Policy and Development and World Agroforestry Centre. http://outputs.worldagroforestry.org/cgibin/koha/opac-detail.pl?biblionumber $=36399$

MBEMBE, E. M., OTIENO, J. D, NYIKAL, R. \& ODENDO, M. (2021). Determinants of Market
Participation by Smallholder Soybean Farmers in Kakamega County, Kenya. A paper presented at the 6th African Conference of Agricultural Economists, September 23-26, 2019, Abuja, Nigeria. http://erepository.uonbi.ac.ke/handle/11295/153633

MBITSEMUNDA, J., \& KARANGWA, A. (2017). Analysis of factors influencing market participation of smallholder bean farmers in Nyanza District of Southern Province, Rwanda. Journal of Agricultural Science, $\quad 9(11)$,

DOI: $10.5539 /$ jas.v9n11p99

MOTTALEB, K, MOHANTY, S., \& NELSON, A. (2015). Strengthening Market Linkages of Farm Households in Developing Countries. Applied Economic Perspectives and Policy, 37(2), 226-242. https://doi.org/10.1093/aepp/ppu026

NYEIN, N. K., SOOJUNG, A., \& SANG, H. L. (2018). Analysis of the factors influencing market participation among smallholder rice farmers in Magway region, central dry zone of Myanmar. Sustainability, $\quad 10, \quad 4441$; https://doi.org/10.3390/su10124441

NYONGESA, D., MABELE, R., ESILABA, A., \& MUTONI, C. (2017). The economics and gender factor in soya bean production and profitability in Kenya: A case of smallholder farms in Western Kenya. International Journal of Agricultural Resources, Governance and Ecology, 13(3), 211-240. http://www.inderscience.com/link.php?id=86991

OMITI, J., OTIENO, D., NYANAMBA, T., \& MCCULLOUGH, E. (2009). Factors influencing the intensity of market participation by smallholder farmers: A case study of rural and peri-urban areas of Kenya. African Journal of Agriculture and Resource Economics, 3: 57-82. DOI: 10.22004/ag.econ.56958

ONYENEKE, R. (2017). Determinants of adoption of improved technologies in rice production in Imo State, Nigeria. African Journal of Agricultural Research, 12(11), 888-896. https://doi.org/10.5897/AJAR2016.11737

OSMANI, M., ISLAM, K., GHOSH, C., \& HOSSAIN, M. E. (2015). Commercialization of smallholder farmers and its welfare outcomes: Evidence from Durgapur Upazila of Rajshahi District, Bangladesh. Journal of World Economic Research, 3(6), 119-126. DOI: 10.11648/j.jwer.20140306.16

PINGALI, L., \& ROSEGRANT, M. (1995). Agricultural commercialization and diversification: Process and polices. Food Policy, 20 (3), 171-185. https://doi.org/10.1016/0306-9192(95)00012-4

RACHIER, G. O. (2001). An overview of soybean (Glycine max L.) production and research in WesternKenya. Paper presented to Soybean Project in Kakamega District Launching Workshop, KARIKakamega.

RANDELA, R., ALEMU, Z. G., \& GROENEWALD, J. A., (2008). Factors enhancing market participation by small-scale cotton farmers. Agrekon, 47(4), 234-267. https://doi.org/10.1080/03031853.2008.9523810

RONO, J. K. (2002). The Impact of the Structural Adjustment Programmes on Kenyan Society. Journal 
of Social Development in Africa, 17(1), 81 - 98. DOI: $10.4314 /$ jsda.v17i1.23847

TODARO, P. M, \& SMITH C. S. (2015). Economic Development, 12th Edition. Harlow, United Kingdom, Pearson Education Limited.

TURAA, E., GOSHUB, D., DEMISIEC, T., \& KENEAD, T. (2016). Determinants of market participation and intensity of marketed surplus of teff producers in Bacho and Dawo Districts of Oromia State, Ethiopia. Journal of Economics and Sustainable Development, 7(1) 21, 13-24. https://core.ac.uk/download/pdf/234647359.pdf

VARIA, N. (2011). Technical Report: Soybean Value Chain. USAID. Southern Africa https://www.satradehub.org/images/stories/download s/pdf/technical_reports/Technical\%20Report\%20\%20Soy\%20Value\%20Chain\%20Report.pdf

WOLDEYOHANES, T., HECKELEI, T., \& SURRY, Y. (2017). Effect of off-farm income on smallholder commercialization: Panel evidence from rural households in Ethiopia. Agricultural Economics, 48(2), 207-218. https://doi.org/10.1111/agec.12327

WOLLNI, M., LEE, D., \& JANICE, T. (2010). Conservation agriculture, organic marketing, and collective action in the Honduran hillsides. Agricultural Economics, 41, 373-384. https://doi.org/10.1111/j.1574-0862.2010.00445.x

WOOLDRIDGE, J. M. (2013). Introductory Econometrics: A modern approach. Mason, $\mathrm{OH}$ : South-Western Cengage Learning.

WORLD BANK (2008). World Development Report 2008: Agriculture for Development. Washington DC, The World Bank.

ZAMASIYA, B., MANGO, N., NYIKAHADZOI, K., \& SIZIBA, S. (2014). Determinants of soybean market participation by smallholder farmers in Zimbabwe. Journal of Development and Agricultural Economics, 6(2), 49-58. https://doi.org/10.5897/JDAE2013.0446 